\title{
Microencapsulation of Probiotic Lactobacillus acidophilus KBL409 by Extrusion Technology to Enhance Survival under Simulated Intestinal and Freeze-Drying Conditions
}

\author{
YunJung Lee ${ }^{1}$, Yu Ra Ji ${ }^{1}$, Sumi Lee ${ }^{2}$, Mi-Jung Choi ${ }^{1}$, and Youngjae Cho ${ }^{1 *}$ \\ ${ }^{1}$ Department of Food Science and Biotechnology of Animal Resources, Konkuk University, Seoul 05029, Republic of Korea \\ ${ }^{2}$ Food Research Institute, Ourhome Ltd., Seongnam 13403, Republic of Korea
}

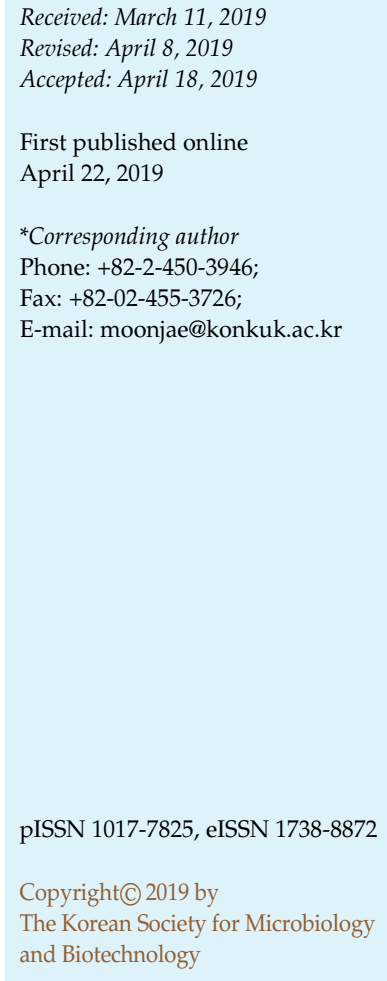

The probiotic Lactobacillus acidophilus KBL409 was encapsulated with alginate (Al) and alginate-chitosan (Al/Chi) through extrusion method. The sizes and zeta potentials of microspheres were measured to confirm encapsulation. To evaluate the protective effect of microspheres against gastrointestinal fluids, all the samples were exposed to simulated gastric fluids (SGFs, $\mathrm{pH} \mathrm{1.5)}$ at $37^{\circ} \mathrm{C}$ for 1 or $2 \mathrm{~h}$, followed by incubation with simulated intestinal fluids (SIFs, $\mathrm{pH}$ 6.5) for $2 \mathrm{~h}$. The mucoadhesive ability of microspheres was evaluated using the intestinal epithelial cell line HT29-MTX. To extend the shelf-life of probiotics, lyoprotectants such as disaccharide and polysaccharide were mixed with free or encapsulated cells during the freeze-drying process. The size of the microspheres demonstrated a narrow distribution, while the zeta potentials of $\mathrm{Al}$ and $\mathrm{Al} /$ Chi-microspheres were $-17.9 \pm 2.3$ and $20.4 \pm 2.6 \mathrm{mV}$, respectively. Among all the samples, Al/Chi-encapsulated cells showed the highest survival rate even after exposure to SGF and SIF. The mucoadhesive abilities of $\mathrm{Al}$ and $\mathrm{Al} /$ Chi-microspheres were higher than 94\%, whereas the free L. acidophilus showed $88.1 \%$ mucoadhesion. Ten percent of sucrose showed over $80 \%$ survival rate in free or encapsulated cells. Therefore, L. acidophilus encapsulated with $\mathrm{Al}$ and $\mathrm{Al} / \mathrm{Chi}$-microspheres showed higher survival rates after exposure to the gastrointestinal tract and better mucoadhesive abilities than the free cells. Also, sucrose showed the highest protective effect of L. acidophilus during the freeze-drying process.

Keywords: Encapsulation, extrusion, Lactobacillus acidophilus, intestinal survival, mucoadhesion, lycoprotectant

\section{Introduction}

Probiotics are living microorganisms with several beneficial effects on the host when consumed in adequate amount. They are also known to inhibit the growth of pathogens, lower cholesterol levels, reduce the risk factors of cancers, and synthesize vitamins [1, 2]. Given these advantages, probiotics have been widely employed in several fields, including food and pharmaceutical industries. The required dose of probiotics varies with the type of probiotic strain. A daily intake of $10^{8}$ to $10^{9}$ colony-forming units (CFUs) of probiotics would be helpful to humans [3].
To exert optimal effects, probiotics must survive under harsh conditions of the intestinal tract and attach to the intestinal villus. Their survival may be affected by acidity, action of enzymes, and in some cases oxygen, during their passage in the host gastrointestinal tract.

Encapsulation is an important technology for the packaging and release of materials, including antibiotic agents, probiotics, and liquids under controlled conditions [4]. The main purpose of the encapsulation of probiotics is to protect them while in the gastrointestinal tract from low $\mathrm{pH}$ and many salts [5]. So far, various techniques have been employed for the encapsulation of probiotics. Of these, the 
main encapsulation methods used in the industry are extrusion, emulsion, and spray drying [6]. The extrusion technique is a process of mixing the probiotic cells with a hydrocolloid solution, followed by extrusion into a bath solution through a nozzle [7]. Nozzle injection needs an axial to produce droplets in the bath solution containing calcium chloride $\left(\mathrm{CaCl}_{2}\right)$ to facilitate polymer hardening [8]. This technique is more convenient and cost effective than others and does not require high temperature or any solvents. So it would be a promising way to improve the viability of the probiotics even after encapsulation process [9].

Various polymers such as polysaccharides and proteins are used in the encapsulation process. Alginate, the most common material used for probiotic encapsulation, is a linear polysaccharide derived from bacteria and algae [10]. It has no toxicity, is regarded as safe, and requires mild gelling conditions for encapsulation [11]. Pure alginate contains several hydrophilic polyanions and exhibits strong mucoadhesive properties [12]. However, alginate microspheres have some disadvantages such as high porosity, which may lead to the breakdown of the microspheres under acidic conditions; hence, other polymers are crosslinked with alginate to overcome the limitations of alginate $[8,13]$. Chitosan is a natural and bioadhesive polymer comprising copolymers of glucosamine and Nacetylglucosamine. It is polycationic under acidic condition and can form ionic cross-linking with anionic materials. Many studies have shown that alginate-chitosan microspheres have reduced porosity as compared with alginate microspheres; these microspheres decrease the leakage of probiotics and are stable at low $\mathrm{pH}$ [14]. Furthermore, they may open the tight junctions of epithelial cells and allow absorption of many beneficial materials into the host body [15]. For these reasons, alginate and chitosan have been widely used for the fabrication of delivery systems.

Freeze-drying is a preferred method that can increase the shelf-life of food products and is easily applicable to them. Probiotics have also been preserved in freeze-dried form because of convenience and successful preservation effect [35]. However, dehydration in the freeze-drying process may damage the cell wall, proteins, DNA, and membrane, so it leads to decreased viability of the probiotics [36]. Therefore, lyoprotectants such as saccharide, alcohol and amino acids are added to probiotics to protect them during the freeze-drying process and the optimal protectant depends on the strain [37].

In the present study, we evaluated the ability of alginate and alginate-chitosan microspheres to encapsulate Lactobacillus acidophilus by the extrusion method. The size of the microspheres was measured and the viability of the encapsulated L. acidophilus was investigated. To assess the protective ability of microspheres, free and encapsulated cells were exposed to simulated saliva fluids, gastric fluids, and intestinal fluids to imitate the human gastrointestinal tract environment, and live cells were counted. Furthermore, in vitro adhesion test of microspheres was conducted using epithelial cells of colon. Also, the survival rate of free and encapsulated L. acidophilus with lyoprotectants was evaluated after the freeze-drying process.

\section{Materials and Methods}

\section{Materials}

L. acidophilus KBL409 newly isolated from healthy Koreans was supplied from Kobiolabs (Korea). MRS broth and agar were purchased from BD Difco (Becton \& Dickinson, USA) and pentasodium tripolyphosphate, chitosan (50-190 kDa, low molecular weight), fluorescein isothiocyanate (FITC, isomer I), and 3-(N-morpholino) propanesulfonic acid (MOPS) were supplied by Sigma-Aldrich (USA). Sodium alginate was obtained from Duchefa Biochemie (Haarlem, Netherlands) and sodium hydroxide $(\mathrm{NaOH})$ and $\mathrm{CaCl}_{2}$ procured from Samchun (Korea) were used for the crosslinking of polymers and depolymerization of the link of polymers. To mimic the gastrointestinal environment, uric acid, pepsin, bovine serum albumin, $\alpha$-amylase, lipase, D-glucose, D-glucuronic acid, D-glucosamine hydrochloride, and bile bovine (purchased from Sigma-Aldrich, USA) were used along with pancreatin (Wako, Japan) and mucin (Kanto chemical, Japan).

\section{Preparation of Cell Culture}

Frozen stock culture of L. acidophilus KBL409 was activated in MRS broth at $37^{\circ} \mathrm{C}$ for $15 \mathrm{~h}$ and reactivated for $12 \mathrm{~h}$. The reactivated cells were centrifuged at $4,000 \times g$ for $20 \mathrm{~min}$ at $4^{\circ} \mathrm{C}$ and washed with saline water. After washing twice, bacterial suspension was centrifuged under the same conditions. The pellets were resuspended in saline water at a final cell concentration of 9 to $10 \log \mathrm{CFU} / \mathrm{ml}$. Viability of cells was evaluated by serial dilution and plating on MRS agar, followed by incubation at $37^{\circ} \mathrm{C}$ for $48 \mathrm{~h}$.

\section{Encapsulation of L. acidophilus KBL409}

A Cellena Extrusion device (Cellena, Spain) was used to manufacture microspheres. Air was filtered through a $0.45-\mu \mathrm{m}$ syringe filter and set to 100 mbar. Alginate solution (1.5\% w/v) adjusted to $\mathrm{pH} 7.3$ was mixed with $L$. acidophilus at a final concentration of $10^{9} \mathrm{CFU} / \mathrm{ml}$. The alginate-L. acidophilus mixture was fed into a $0.1 \mathrm{M} \mathrm{CaCl}_{2}$ solution through a nozzle at a feeding rate of $0.02 \mathrm{ml} / \mathrm{h}$. The distance between the bottom of the nozzle and the surface of $\mathrm{CaCl}_{2}$ solution was $3 \mathrm{~cm}$ (Fig. 1). The beads were allowed to harden at $4^{\circ} \mathrm{C}$ for $1 \mathrm{~h}$ and the supernatant was 
A

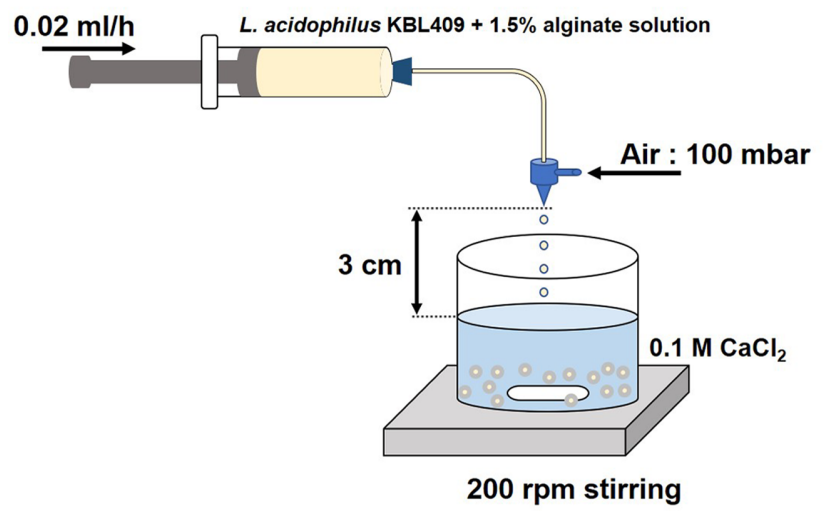

B

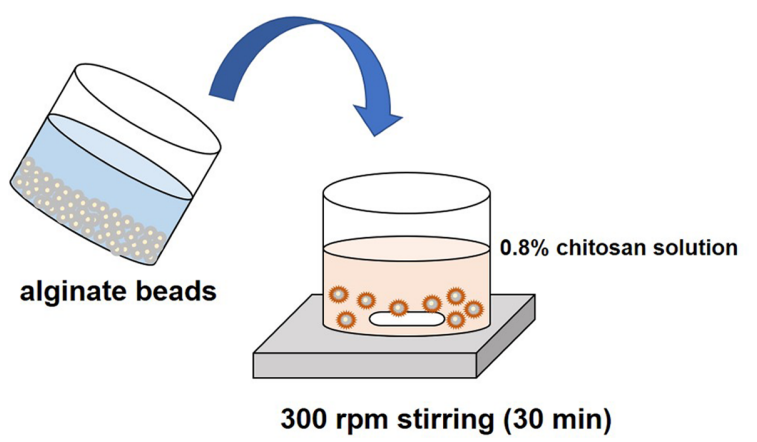

Fig. 1. Encapsulation process of alginate-microsphere (A) and alginate/chitosan-microsphere (B).

removed. To exclude cells not entrapped, alginate microspheres (Al-microspheres) were washed twice with sterilized $0.85 \%(\mathrm{w} / \mathrm{v})$ sodium chloride $(\mathrm{NaCl})$ solution. To encapsulate alginate microspheres with chitosan, $0.8 \%(\mathrm{w} / \mathrm{v})$ chitosan was dissolved in $1 \%(\mathrm{v} / \mathrm{v})$ acetic acid solution and the $\mathrm{pH}$ of the solution was adjusted to 5.7-6 using $1 \mathrm{~N} \mathrm{NaOH}$. The mixture was filtered with Whatman paper and the volume of the mixture was adjusted to $100 \mathrm{ml}$ before autoclaving at $121^{\circ} \mathrm{C}$ for $15 \mathrm{~min}$. A total of $10 \mathrm{~g}$ of rinsed alginate microspheres were mixed with $30 \mathrm{ml}$ of sterilized chitosan solution at $300 \mathrm{rpm}$ for $30 \mathrm{~min}$. The alginate/chitosan microspheres ( $\mathrm{Al} / \mathrm{Chi}$-microspheres) were rinsed twice with sterilized $0.85 \% \mathrm{NaCl}$ and allowed to stand at $4^{\circ} \mathrm{C}$ for $1 \mathrm{~h}$.

\section{Encapsulation Efficiency and Viability of Probiotics}

To break the encapsulated polymers, the $\mathrm{pH}$ of $0.1 \mathrm{M}$ pentasodium tripolyphosphate solution dissolved in deionized water was adjusted to 7 before autoclaving at $121^{\circ} \mathrm{C}$ for $15 \mathrm{~min}$. To count the number of encapsulated cells, $1 \mathrm{~g}$ of $\mathrm{Al}$ microspheres were mixed with $9 \mathrm{ml}$ of $0.1 \mathrm{M}$ pentasodium tripolyphosphate solution at $37^{\circ} \mathrm{C}$ with horizontal shaking at $100 \mathrm{rpm}$ for $1 \mathrm{~h}$, while $\mathrm{Al} / \mathrm{Chi}$-microspheres were incubated under the same conditions for $2 \mathrm{~h}$. The cells were diluted and plated on MRS agar. In the process of preparing microspheres, the cells not entrapped were obtained from the supernatant, diluted to obtain an adequate concentration, and plated on MRS agar. The plates were incubated at $37^{\circ} \mathrm{C}$ for $48 \mathrm{~h}$ before counting the number of cells. Encapsulation efficiency was calculated as follows:

$$
\operatorname{EE}(\%)=N_{E} /\left(N_{E}+N_{n}\right) \times 100
$$

$N_{E}$ is the number of cells in beads and $N_{n}$ is the number of the cells not entrapped (CFU/g).

Before encapsulation, L. acidophilus was stained with a fluorescein dye (LIVE/DEAD BacLight Bacterial Viability Kit, Invitrogen, USA); live cells were labeled green, while dead cells were labeled red. To evaluate cell viability before and after encapsulation, the dyed cells were encapsulated with alginate as described under the section of encapsulation of L. acidophilus KBL409. After encapsulation, the cells were observed using a Tieclipse fluorescence microscope (Nikon, Japan). The excitation/ emission range was $480 / 500 \mathrm{~nm}$ for green color and 490/635 nm for red color. The number of live and dead cells was counted with color intensity using analysis software (NIS-Elements $\mathrm{Br} 4.60$, Nikon). Cell viability during encapsulation was calculated as follows:

Cell viability $(\%)=I_{G} /\left(I_{G}+I_{R}\right) \times 100$

$I_{G}$ is the intensity of green color indicative of the number of live cells and $I_{R}$ indicated the number of dead cells.

\section{Size and Zeta Potential of Microspheres}

After rinsing and incubation for $2 \mathrm{~h}$, the size of $\mathrm{Al}$ and $\mathrm{Al} / \mathrm{Chi}-$ microspheres was measured using a laser diffraction particle size analyzer (Mastersizer 3000E, Malvern Instruments, UK). All the measurements were performed in triplicates. To confirm the encapsulated layer of alginate and chitosan, the zeta potentials of $\mathrm{Al}$ and $\mathrm{Al} / \mathrm{Chi}$-microspheres were measured using a Zetasizer (Nano ZS, Malvern Instruments, UK). Rinsed microspheres were loaded with deionized water in small amounts into a capillary cell and all the samples were analyzed at a scattering angle of $90^{\circ}$ at $25^{\circ} \mathrm{C}$.

Survival of L. acidophilus under the Conditions of Simulated Gastrointestinal Tract

The survival of free cells, Al-encapsulated cells, and Al/Chiencapsulated cells was evaluated under in vitro gastrointestinal tract conditions. The simulated saliva fluids (SSF), simulated gastric fluids (SGF), and simulated intestinal fluids (SIF) were prepared using a modified method [16, 17]. The compositions of SSF, SGF, and SIF are described in Table 1. Inorganic and organic compounds were dissolved in $100 \mathrm{ml}$ of distilled water and mixed with each other. The volume was adjusted to $500 \mathrm{ml}$ with distilled water. Enzymes were added to the mixture and all the solutions were filtered with a $0.45-\mu \mathrm{m}$ filter. All the simulated fluids were stored at $4^{\circ} \mathrm{C}$ and used within $24 \mathrm{~h}$.

To simulate the oral phase, $1 \mathrm{ml}$ of free cells $\left(10^{9} \mathrm{CFU} / \mathrm{ml}\right)$ or $1 \mathrm{~g}$ of beads $\left(10^{9} \mathrm{CFU} / \mathrm{g}\right)$ were mixed with $9 \mathrm{ml}$ of SSF at $37^{\circ} \mathrm{C}$ and 
Table 1. Composition of simulated gastrointestinal fluids.

\begin{tabular}{|c|c|c|c|c|c|c|}
\hline \multirow{2}{*}{ Concentration } & \multicolumn{2}{|c|}{$\mathrm{SSF}^{*}$} & \multicolumn{2}{|l|}{ SGF } & \multicolumn{2}{|c|}{ SIF } \\
\hline & \multicolumn{2}{|c|}{$\mathrm{pH} 7( \pm 0.2)$} & \multicolumn{2}{|l|}{$\mathrm{pH} 1.5( \pm 0.02)$} & \multicolumn{2}{|c|}{$\mathrm{pH} 6.5( \pm 0.01)$} \\
\hline \multirow[t]{6}{*}{ Inorganic compound $(\mathrm{g} / \mathrm{l})$} & $\mathrm{NaCl}$ & 175.3 & $\mathrm{NaCl}$ & 175.3 & $\mathrm{NaCl}$ & 175.3 \\
\hline & $\mathrm{KCl}$ & 89.6 & $\mathrm{KCl}$ & 89.6 & $\mathrm{KCl}$ & 89.6 \\
\hline & $\mathrm{NaH}_{2} \mathrm{PO}_{4}$ & 88.8 & $\mathrm{NaH}_{2} \mathrm{PO}_{4}$ & 88.8 & $\mathrm{NaHCO}_{3}$ & 84.7 \\
\hline & $\mathrm{Na}_{2} \mathrm{PO}_{4}$ & 57.0 & $\mathrm{NH}_{4} \mathrm{Cl}$ & 30.6 & $\mathrm{CaCl}_{2}$ & 22.2 \\
\hline & $\mathrm{NaOH}$ & 40.0 & $\mathrm{CaCl}_{2}$ & 22.2 & $\mathrm{NaH}_{2} \mathrm{PO}_{4}$ & 8.0 \\
\hline & $\mathrm{KSCN}$ & 20.0 & & & $\mathrm{MgCl}_{2}$ & 5.0 \\
\hline \multirow[t]{4}{*}{ Organic compound (g/l) } & Urea & 25 & Glucose & 65 & Urea & 25 \\
\hline & & & Glucosamine hydrochloride & 33 & & \\
\hline & & & Urea & 25 & & \\
\hline & & & Glucuronic acid & 2 & & \\
\hline \multirow[t]{4}{*}{ Enzyme (mg) } & Amylase & 145 & BSA & 1,000 & Bile & 6,000 \\
\hline & Mucin & 50 & Pepsin & 2,500 & Pancreatin & 3,000 \\
\hline & Uric acid & 15 & Mucin & 3,000 & BSA & 2,800 \\
\hline & & & & & Lipase & 500 \\
\hline
\end{tabular}

*SSF, SGF, and SIF stand for simulated saliva fluid, simulated gastric fluid, and simulated intestinal fluid, respectively.

$60 \mathrm{rpm}$ for $2 \mathrm{~min}$. About $1 \mathrm{ml}$ of the oral phase was collected for sampling and $5 \mathrm{ml}$ of the oral mixture was carried to $5 \mathrm{ml}$ of SGF. To compare the effects of SGF, the exposure time was set to 1 and $2 \mathrm{~h}$. The gastric mixture was incubated at $37^{\circ} \mathrm{C}$ and $60 \mathrm{rpm}$, and $1 \mathrm{ml}$ of sample was used for counting. To assess intestinal tolerance, $5 \mathrm{ml}$ of the gastric mixture was added to $7.5 \mathrm{ml}$ of SIF and incubated at $37^{\circ} \mathrm{C}$ and $60 \mathrm{rpm}$ for $2 \mathrm{~h}$ and $4 \mathrm{~h}$ before sampling. After incubation, $1 \mathrm{ml}$ of sample was collected for sampling. Almicrospheres and $\mathrm{Al} / \mathrm{Chi}$-microspheres were added to $9 \mathrm{ml}$ of $0.1 \mathrm{M}$ pentasodium tripolyphosphate to facilitate polymer breakdown at $37^{\circ} \mathrm{C}$ with horizontal shaking at $100 \mathrm{rpm}$ for $1 \mathrm{~h}$ (Almicrospheres) or $2 \mathrm{~h}$ (Al/Chi-microspheres). Depolymerized cells from microspheres and free cells were diluted at adequate concentrations and plated on MRS agar. All the samples were incubated at $37^{\circ} \mathrm{C}$ for $48 \mathrm{~h}$ before cell enumeration.

\section{Preparation of FITC-Labeled Chitosan and Microspheres}

FITC-labeled chitosan was synthesized as previously described [6]. Chitosan ( $1 \% \mathrm{w} / \mathrm{v})$ was dissolved in $1 \%$ acetic acid solution, followed by the addition of $100 \mathrm{ml}$ of dehydrated methanol and FITC ( $2 \mathrm{mg} / \mathrm{ml}$ in methanol, $50 \mathrm{ml})$. Conjugation between FITC and chitosan was carried out in the dark at room temperature for $3 \mathrm{~h}$. After precipitation with a liter of $0.1 \mathrm{M} \mathrm{NaOH}$, the precipitate was filtered and dialyzed in deionized water, which was replaced every day until FITC disappeared in the dialysis jar. The dialyzed product was freeze-dried at $-78^{\circ} \mathrm{C}$ and 5 mbar for $96 \mathrm{~h}$. Freezedried FITC-labeled chitosan was stored under $-18^{\circ} \mathrm{C}$ before further use. To prepare FITC-chitosan-encapsulated cells, the method described in the section of encapsulation of L. acidophilus KBL 409 was used, and chitosan was replaced with FITC-labeled chitosan in the encapsulating solution.

\section{In Vitro Mucoadhesive Test}

Mucoadhesion was evaluated with modifications to the method described previously [12]. HT29-MTX human epithelial cells were cultured in Dulbecco's modified Eagle's medium (DMEM, GlutaMAX, USA) containing $4.5 \mathrm{~g} / 1$ glucose and supplemented with $25 \mathrm{mmol} / \mathrm{l}$ HEPES buffer and 10\% (v/v) fetal bovine serum at $37^{\circ} \mathrm{C}$ under modified atmosphere $\left(5 \% \mathrm{CO}_{2} / 95 \%\right.$ air). The culture medium was changed every 2 days. HT29-MTX cells were seeded into 12-well plates (SPL Life Science, Korea) at a density of $5 \times 10^{4}$ cells $/ \mathrm{cm}^{2}$ and cultured until confluence. One gram of encapsulated cells or $1 \mathrm{ml}$ of free cells (equivalent to $10^{9} \mathrm{CFU}$ ) previously washed twice with phosphate-buffered saline (PBS) were added to each well and incubated at $37^{\circ} \mathrm{C}$ under $5 \% \mathrm{CO}_{2}$ / $95 \%$ air for $1 \mathrm{~h}$ to facilitate adhesion. After incubation, each well was washed twice with $1 \mathrm{ml}$ DMEM to remove the non-adhered microspheres. To detach any adhered microspheres or free cells from HT29-MTX cells, the monolayers were trypsinized with $200 \mu \mathrm{l}$ of $0.25 \%$ trypsin-ethylenediaminetetraacetic acid (EDTA) solution. The encapsulated cells were mixed with $0.1 \mathrm{M}$ of pentasodium tripolyphosphate solution to break polymers, as described above. Depolymerized microsphere samples and free cells were counted by plating on MRS agar after incubation at $37^{\circ} \mathrm{C}$ for $48 \mathrm{~h}$. To observe the adhesion of $\mathrm{Al} / \mathrm{Chi}$-microspheres on HT29-MTX cells, the microspheres were capsulated with FITC- 
labeled chitosan. The method previously described was repeated. After the mucoadhesion test, the FITC-labeled chitosan-encapsulated cells were observed with fluorescence microscopy $(480 / 500 \mathrm{~nm})$.

\section{Freeze-Drying and Survivability}

A suspension of L. acidophilus KBL409 was mixed with solution containing lyoprotectants. As low molecular lyoprotectants, 10\% of glucose, trehalose, lactose, sucrose, and fructose were singly used. Prebiotics including 2\% of maltodextrin, inulin, and corn starch were also singly used as lyoprotectants. For producing encapsulated cells, alginate solution was mixed with each lyoprotectant solution and extruded to calcium chloride solution by extrusion method. Chitosan encapsulating followed the same method in the section of encapsulation of L. acidophilus KBL409. All the samples were frozen at $-30^{\circ} \mathrm{C}$ for overnight and freeze dried for $48 \mathrm{~h}$.

To evaluate the survivability of cells, $10 \mathrm{mg}$ of freeze-dried cells were mixed well with $0.99 \mathrm{ml}$ of $0.85 \%$ sodium chloride solution. Then, the method described in the section of survival of L. acidophilus under the conditions of simulated gastrointestinal tract was repeated to depolymerize cells and count the number of cells.

\section{Statistical Analysis}

All statistical analyses were performed using one-way ANOVA with SPSS Statistics Ver. 24.0. All the mean comparisons were done by Duncan's multiple range test and differences were considered significant $(p<0.05)$. The data were presented as the mean \pm standard error by triplicate experiments.

\section{Results and Discussion}

\section{Encapsulation Efficiency and Cell Viability}

Encapsulation efficiencies of the two microsphere types are shown in Table 2. The number of encapsulated L. acidophilus in Al-microspheres was $4.7 \times 10^{8} \mathrm{CFU} / \mathrm{g}$, while that of cells not entrapped was $1.0 \times 10^{6} \mathrm{CFU} / \mathrm{g}$. The encapsulation efficiency of Al-microsphere was calculated to be $99.7 \%$ from Equation in the section of encapsulation efficiency and viability of probiotics. The number of encapsulated cells in $\mathrm{Al} / \mathrm{Chi}$-microsphere and cells not entrapped were found to be as $2.3 \times 10^{8}$ and $5.0 \times 10^{5} \mathrm{CFU} / \mathrm{g}$,
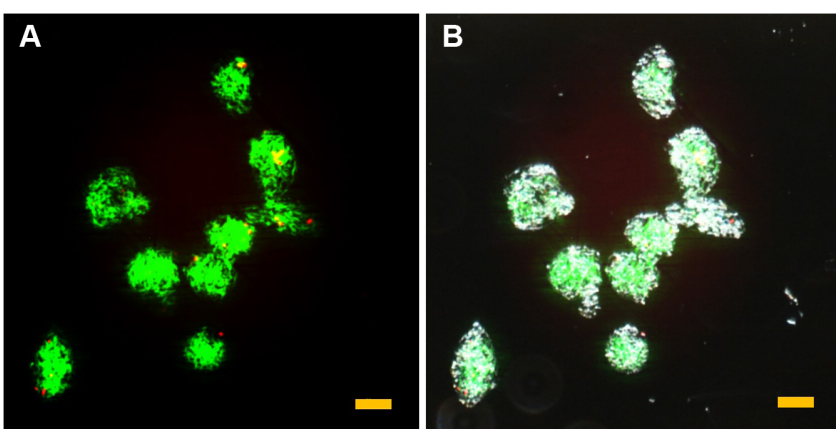

Fig. 2. Fluorescence image of cell viability in alginate microspheres (A), and merged fluorescence and optical microscopy images (B).

Green indicates live cells and red indicates dead cells after extrusion at $\times 200$ magnification. Scale bar (yellow bar) $=50 \mu \mathrm{m}$.

respectively. Encapsulation efficiency of $\mathrm{Al} / \mathrm{Chi}$-microsphere was $99.7 \%$ (same value as that of Al-microsphere). Many studies on encapsulation with extrusion method have reported similar results. L. acidophilus was encapsulated into polyphenol-alginate and the encapsulation efficiency of beads was reported to be above 96\% [18]. Using alginate and psyllium seed for the encapsulation of L. acidophilus had reported an encapsulation efficacy of approximately 98\% [19]. Encapsulated L. bulgaricus through extrusion method with alginate and pure milk comprising 3.1\% protein and $3.5 \%$ fat also had reported an encapsulation efficiency of $99 \%$ [1]. Pea protein isolate-alginate capsule entrapping Bifidobacterium and prebiotics was found to show an encapsulation efficiency of more than 98\% [20]. The change in cell viability after extrusion process was also measured using analysis software (Fig. 2). The analysis of color intensity revealed cell viability of approximately 98.7\%; therefore, the extrusion process had no impact on cell viability.

\section{Size and Zeta Potential of Microspheres}

Size distribution of microspheres is described in Fig. 3. The average size of Al-microspheres was $93.4 \pm 0.6 \mu \mathrm{m}$. Al/

Table 2. Number of encapsulated cells in alginate-microspheres and alginate/chitosan-microspheres.

\begin{tabular}{lccc}
\hline & $\begin{array}{c}\text { Encapsulated cells } \\
(\mathrm{CFU} / \mathrm{g})\end{array}$ & $\begin{array}{c}\text { Cells not entrapped } \\
(\mathrm{CFU} / \mathrm{g})\end{array}$ & $\begin{array}{c}\text { Encapsulation efficiency } \\
(\% * *\end{array}$ \\
\hline Al-microsphere* & $4.7( \pm 1.1) \times 10^{8}$ & $1.0( \pm 1.2) \times 10^{6}$ & 99.7 \\
Al/Chi-microsphere & $2.3( \pm 1.7) \times 10^{8}$ & $5.0( \pm 1.0) \times 10^{5}$ & 99.7
\end{tabular}

${ }^{*}$ Al-microsphere means L. acidophilus encapsulated with alginate.

**Al/Chi-microsphere means L. acidophilus encapsulated with alginate and chitosan.

***Encapsulation efficiency was calculated from the number of encapsulated cells and cells not entrapped. 


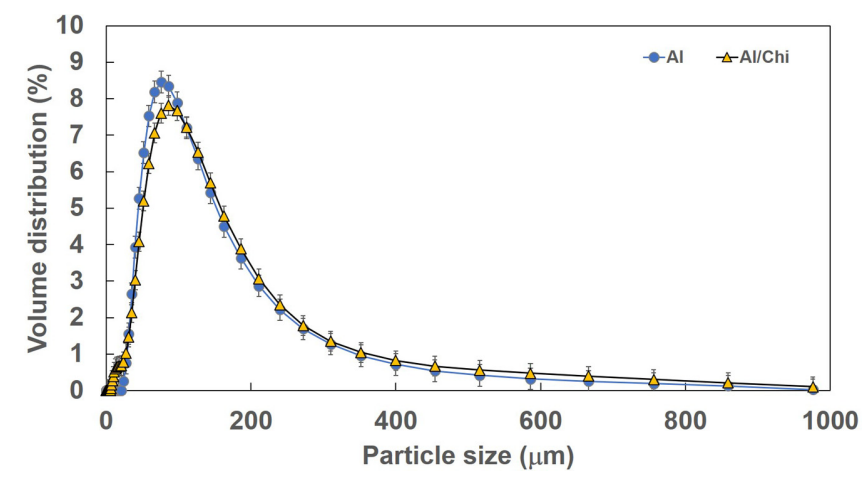

Fig. 3. Size distribution of alginate and alginate/chitosanmicrospheres.

Chi-microspheres showed a slightly larger size of $97.1 \pm$ $0.4 \mu \mathrm{m}$. The increase in the particle size was indicative of the deposition of the chitosan layer through electrolytic linkage. The narrow particle size distribution was suggestive of the homogeneity of the produced microspheres [21]. The mean particle size of microspheres is one of the important characteristics that determine encapsulation efficiency and stability [1]. The size of microspheres may be controlled by the concentrations of hydrocolloid solutions and nozzle size [22]. Their size also might affect sensory evaluation. Alginate microspheres encapsulating Bifidobacterium showed no negative sensory impact at size below $100 \mu \mathrm{m}$ [23].

Zeta potential is a fundamental parameter of doublelayer models that describes electrochemical properties [24]. The zeta potentials of $\mathrm{Al}$ and $\mathrm{Al} / \mathrm{Chi}$-microspheres were $-17.9 \pm 2.3$ and $20.4 \pm 2.6 \mathrm{mV}$, respectively. As alginate carried a negative charge and chitosan is positively charged [25], the Al/Chi-microspheres were confirmed to be uniformly layered with alginate and chitosan.

\section{Survival of the Encapsulated L. acidophilus under Simulated Oral and Gastric Phases}

Microencapsulation strategies were evaluated in simulated oral and gastric phases, and free cells were used as control. Fig. 4 shows the survival of the encapsulated cells under oral and gastric conditions. In the oral phase, survival rates showed no significant decrease in all treatment groups (0.74-1.13 $\log$ [87.3-91.8\%]) as compared with the survival rate at the initial phase. After $60 \mathrm{~min}$ incubation in the gastric phase, the survival ability of cells was not significantly reduced in all treatment groups (83.6-87.0\%) as compared with the initial condition. After $120 \mathrm{~min}$ of exposure to gastric phase, the survival rates significantly decreased in all treatment groups $(p<0.05)$. Free cells

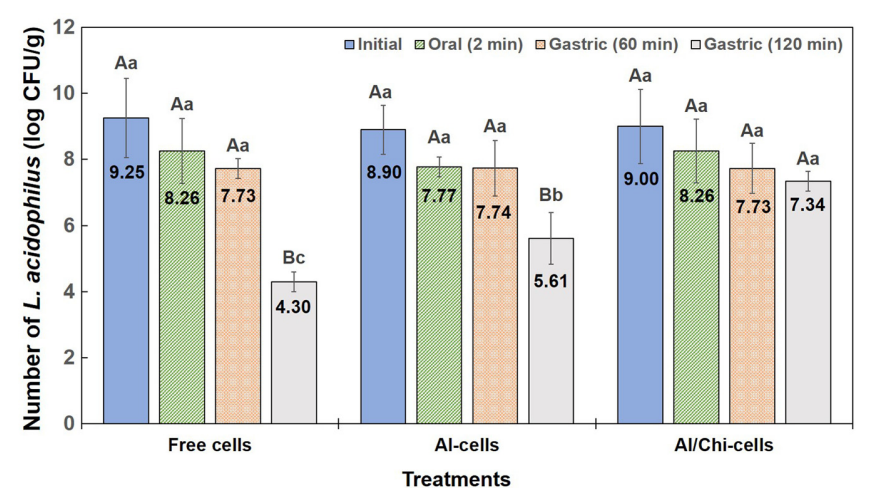

Fig. 4. Survival rate of free cells, alginate-encapsulated cells (Al-cells), and alginate/chitosan-encapsulated cells (Al/Chicells) exposed to oral and gastric phases.

(A-C) Different letters within same treatment (encapsulated and free cells) indicate statistical significance $(p<0.05)$. (a-c) Different letters with same exposure time indicate statistical significance $(p<0.05)$.

showed a dramatic decrease in survival rate $(46.5 \%$ [4.95 log reduction]), while $\mathrm{Al}$ - and $\mathrm{Al} / \mathrm{Chi}$-encapsulated cells showed 63\% (3.29 log reduction) and 81.6\% (1.66 log reduction), respectively. Double-layered encapsulation with alginate and chitosan provided considerable protection against acidic conditions. These results are in line with those reported in previous studies, wherein the encapsulation with alginate and chitosan increased the viability of Lactobacilli and Bifidobacteria upon exposure to acidic condition. The number of non-encapsulated L. gasseri and B. bifidum decreased from $10^{9}$ to $10 \mathrm{CFU} / \mathrm{ml}$ after incubation in simulated gastric juice ( $\mathrm{pH} 2)$ for 2 and $1 \mathrm{~h}$, respectively, whereas more than $80 \% \mathrm{Al} / \mathrm{Chi}$-encapsulated cells survived under these conditions [26]. L. lactis encapsulated with alginate-chitosan also showed high viability (75.0\%) upon exposure to gastric condition for $2 \mathrm{~h}$, whereas the number of free cells was less than $1 \log$ within 90 min of treatment [27]. Free B. breve were undetected in the presence of gastric condition ( $\mathrm{pH} \mathrm{2}$ ) for $60 \mathrm{~min}$, while the viability of $\mathrm{Al} / \mathrm{Chi}$-encapsulated cells $(76.8 \%)$ further improved [6]. The decrease in the number of free L. acidophilus cells was twice that of the number of alginate-starch-encapsulated cells in response to exposure to acidic condition ( $\mathrm{pH} 2$ ) and high concentration (approximately $2 \%$ ) of salt and bile [28].

Survival of the Encapsulated L. acidophilus under Simulated Gastric and Intestinal Phases

After exposure to SGF (1 and $2 \mathrm{~h}$ ), all the groups were incubated with SIF for $2 \mathrm{~h}$ and $4 \mathrm{~h}$. The number of treatments decreased depending on the exposure time to 
Table 3. The number of encapsulated and free cells after exposure to SGF and SIF.

\begin{tabular}{|c|c|c|c|c|}
\hline \multirow{2}{*}{ Gastric phase (h) } & \multirow{2}{*}{ Intestinal phase (h) } & \multirow{2}{*}{$\begin{array}{c}\text { Free cells } \\
(\log C F U / g)\end{array}$} & \multicolumn{2}{|c|}{ Encapsulated cells (log CFU/g) } \\
\hline & & & $\mathrm{Al}$ & $\mathrm{Al} / \mathrm{Chi}$ \\
\hline 0 & 0 & $\begin{array}{c}9.44 \pm 0.56^{\mathrm{Aa}} \\
(100 \%)^{*}\end{array}$ & $\begin{array}{c}9.24 \pm 0.67^{\mathrm{Aa}} \\
(100 \%)\end{array}$ & $\begin{array}{c}9.25 \pm 0.58^{\mathrm{Aa}} \\
(100 \%)\end{array}$ \\
\hline \multirow[t]{3}{*}{1} & 0 & $\begin{array}{c}7.21 \pm 1.13^{\mathrm{Ba}} \\
(76.4 \%)\end{array}$ & $\begin{array}{c}7.86 \pm 0.79^{\mathrm{Ba}} \\
(85.1 \%)\end{array}$ & $\begin{array}{c}7.98 \pm 0.75^{\mathrm{Ba}} \\
(86.3 \%)\end{array}$ \\
\hline & 2 & $\begin{array}{c}5.44 \pm 0.40^{\mathrm{Ca}} \\
\quad(57.6 \%)\end{array}$ & $\begin{array}{c}6.18 \pm 0.91^{\mathrm{Ca}} \\
(66.9 \%)\end{array}$ & $\begin{array}{c}6.46 \pm 0.51^{\mathrm{CDa}} \\
\quad(69.8 \%)\end{array}$ \\
\hline & 4 & $\begin{array}{c}3.47 \pm 0.32^{\mathrm{Dc}} \\
(36.7 \%)\end{array}$ & $\begin{array}{c}4.59 \pm 0.49^{\mathrm{Db}} \\
\quad(49.7 \%)\end{array}$ & $\begin{array}{c}5.94 \pm 0.66^{\mathrm{Da}} \\
\quad(64.2 \%)\end{array}$ \\
\hline \multirow[t]{3}{*}{2} & 0 & $\begin{array}{c}4.32 \pm 0.42^{\mathrm{CDC}} \\
\quad(45.7 \%)\end{array}$ & $\begin{array}{c}5.93 \pm 0.66^{\mathrm{Cb}} \\
(64.2 \%)\end{array}$ & $\begin{array}{c}7.53 \pm 0.83^{\mathrm{BCa}} \\
(81.4 \%)\end{array}$ \\
\hline & 2 & $\begin{array}{c}2.96 \pm 0.42^{\mathrm{Db}} \\
(31.4 \%)\end{array}$ & $\begin{array}{c}3.78 \pm 0.96^{\mathrm{Dab}} \\
(41.0 \%)\end{array}$ & $\begin{array}{c}4.50 \pm 0.30^{\mathrm{Ea}} \\
\quad(48.7 \%)\end{array}$ \\
\hline & 4 & $\begin{array}{c}2.31 \pm 0.86^{\mathrm{Db}} \\
(24.4 \%)\end{array}$ & $\begin{array}{c}3.45 \pm 0.30^{\mathrm{Dab}} \\
(37.3 \%)\end{array}$ & $\begin{array}{c}3.79 \pm 0.61^{\mathrm{Ea}} \\
(40.9 \%)\end{array}$ \\
\hline
\end{tabular}

\footnotetext{
${ }^{\mathrm{A}-\mathrm{E}}$ Different letters within same treatment (encapsulated and free cells) are significantly different $(p<0.05)$.

${ }^{a-c}$ Different letters with same exposure time are significantly different $(p<0.05)$.

*Percentage in parentheses means survival rate compared to initial number of cells.
}

\section{SGF and SIF (Table 3).}

Bacterial number significantly decreased in all treatment groups following transfer to the gastric and intestinal phases. The exposure to gastric phase for $1 \mathrm{~h}$ and intestinal phase for $2 \mathrm{~h}$ decreased the bacterial count in $\mathrm{Al}$ (66.9\%) and $\mathrm{Al} / \mathrm{Chi}$-microsphere $(69.8 \%)$ groups as compared with free cells $(57.6 \%)$. Subsequently, exposure to intestinal phase for $4 \mathrm{~h}$ decreased the bacterial count in $\mathrm{Al}(49.7 \%)$ and $\mathrm{Al} / \mathrm{Chi}$-microsphere $(64.2 \%)$ as compared to free cells $(36.7 \%)$. The exposure to gastric phase for $2 \mathrm{~h}$ and intestinal phase for $2 \mathrm{~h}$ reduced the decrease in the number of bacterial cells in $\mathrm{Al}(41 \%)$ and $\mathrm{Al} / \mathrm{Chi}$ - microsphere (48.7\%) groups as compared with free cells $(31.4 \%)$. Continually, exposure to intestinal phase for $4 \mathrm{~h}$ decreased the bacterial count in $\mathrm{Al}(37.3 \%)$ and $\mathrm{Al} / \mathrm{Chi}-$ microsphere $(40.9 \%)$ as compared with free cells $(24.4 \%)$. Encapsulation with alginate and chitosan provided considerable protection from the intestinal conditions. An alginate-gelatinized starch microcapsule with chitosan encapsulation effectively protected L. casei and B. bifidum exposed to simulated intestinal juice ( $\mathrm{pH} 8$ ) for $120 \mathrm{~min}$. The initial number of cells was approximately $11 \log$ CFU and showed a decrease of less than $6 \log \mathrm{CFU}$, while the decrease in the population of free cells was more than $6 \log$ CFU [29]. Many studies have reported that chitosan could protect probiotics from bile salts through an ion-exchange reaction [30,31].

\section{Mucoadhesion of Microspheres}

The results of mucoadhesion test are described in Table 4 . Mucoadhesion rates of $\mathrm{Al}$ and $\mathrm{Al} / \mathrm{Chi}$-microspheres were 95.6\% (9.37 $\pm 0.20 \mathrm{log} \mathrm{CFU} / \mathrm{g})$ and $94.3 \%$ (9.24 $\pm 0.17 \mathrm{log}$ $\mathrm{CFU} / \mathrm{g}$ ), respectively, whereas the rate observed for free cells was $88.1 \%(8.63 \pm 0.14 \log \mathrm{CFU} / \mathrm{g})$. Thus, the number of bacteria adhered to HT29-MTX cells was higher in the presence of $\mathrm{Al}$ and $\mathrm{Al} / \mathrm{Chi}$-microspheres than that observed following incubation with free cells, consistent with the conditions in the human intestine. Thus, these microspheres are suitable for studying cell-bacterium interactions $(p<$ 0.05) [32].

Fig. 5 demonstrates the attachment of the FITC-chitosanencapsulated microspheres to colon cells. Therefore, $\mathrm{Al}$ and $\mathrm{Al} /$ Chi-microspheres may be suitable for the intestinetargeted delivery of molecules. These results were consistent with those previously reported. Microcapsules layered with

Table 4. Mucoadhesive test of Lactobacillus acidophilus KBL409 on HT29-MTX cells.

\begin{tabular}{lccc}
\hline & \multirow{2}{*}{ Free cells } & \multicolumn{2}{c}{ Encapsulated cells } \\
\cline { 3 - 4 } & & $\mathrm{Al}$ & $\mathrm{Al} / \mathrm{Chi}$ \\
\hline Initial cells $(\log \mathrm{CFU} / \mathrm{g})$ & $9.80 \pm 1.14^{\mathrm{A}}$ & $9.80 \pm 1.20^{\mathrm{A}}$ & $9.80 \pm 0.30^{\mathrm{A}}$ \\
Adhered cells $(\log \mathrm{CFU} / \mathrm{g})$ & $8.63 \pm 0.14^{\mathrm{B}}$ & $9.37 \pm 0.20^{\mathrm{A}}$ & $9.24 \pm 0.17^{\mathrm{A}}$ \\
Adhesive rate $(\%)$ & 88.1 & 95.6 & 94.3 \\
\hline${ }^{\mathrm{A}-\mathrm{B}}$ Different letters with same time are significantly different $(p<0.05)$.
\end{tabular}



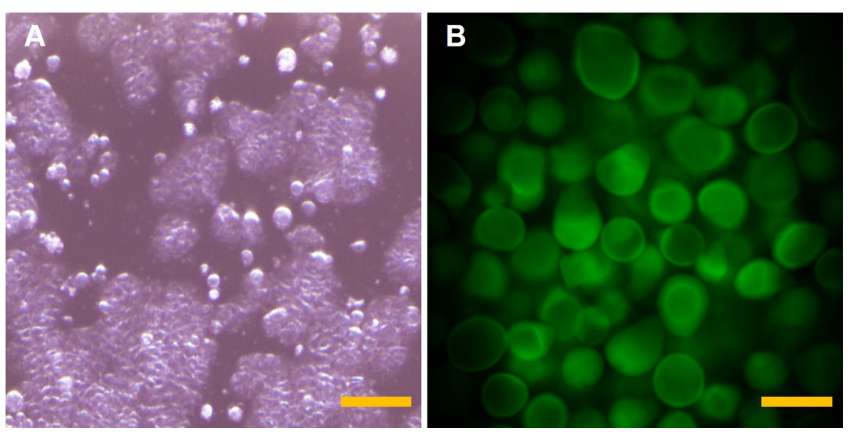

Fig. 5. HT29-MTX cells (A) and FITC-labeled chitosanencapsulated cells (B) attached to HT29-MTX cells at $\times 200$ magnification.

Scale bar (yellow bar) $=100 \mu \mathrm{m}$.

alginate and chitosan and encapsulating Bacillus coagulans showed improved adhesiveness to mucus cells [33]. Also, an alginate-chitosan microcapsule containing L. reuteri was reported as an effective delivery system to the intestine both in vitro and in vivo [34]. The in vitro results showed that the number of encapsulated cells in the gizzard was approximately $50 \%$ of the initial number, whereas free cells were undetected at the same site. In vivo test results of this study revealed the attachment of 5-8 $\log$ CFU of L. reuteri after injection of $10 \log$ CFU.

\section{Survival Rate of L. acidophilus after Freeze-Drying}

In the survival rate of free cells, all lyoprotectants showed protective effects compared to control with an exception of inulin (Fig. 6). Especially, free cells with glucose and sucrose showed higher survival rates as $97.6 \%$ and $95.3 \%$, respectively, compared to free cells with other lyoprotectants. Inulin, known as a prebiotic, showed the lowest survival rate $(59 \%)$ in free cells and it is correspondent to the previous study that L. rhamnosus with inulin had lower survival rate than others after freeze-drying [38]. As the concentrations of oligosaccharides such as inulin, corn starch, and maltodextrin increased, their protective effects on freeze-dried cells were reported to be increased [42]. However, the previous study also reported that the concentration of lyoprotectants was higher than $10 \%$, leading to reduced viability of cells because of the crystallization of lyoprotectants [42]. This is due to the structure of fibers, degree of polymerization and molecular weight having some minor effect on the freeze-drying process [38]. For encapsulated cells, Al-cells without any protectant showed the highest survival rate, but $\mathrm{Al} / \mathrm{Chi}-$ cells showed the higher survival rate when sucrose was added. The major factors of cell survival in the freezedrying process are osmotic pressure and ice crystallization resulting in membrane injury [41]. Generally, sugars are known as lyoprotectants because they can hold water and prevent protein denaturation. Also, disaccharides have been reported as an effective way to protect cells during the drying process $[39,40]$.

In the present study, L. acidophilus was encapsulated within alginate and alginate-chitosan microspheres by

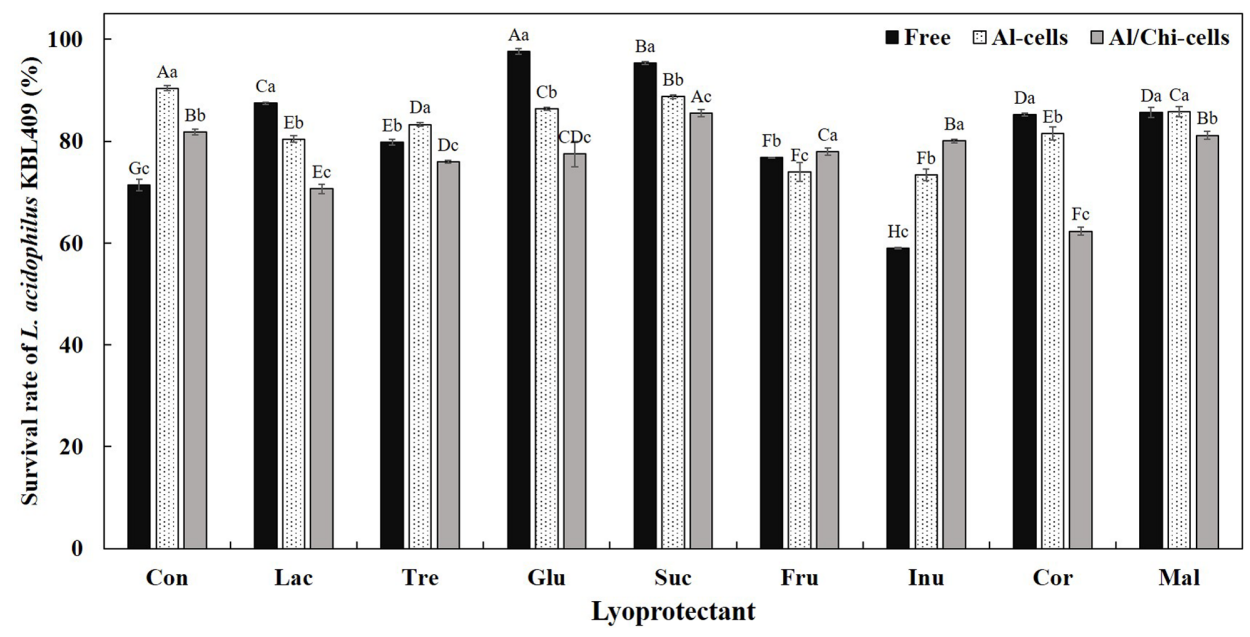

Fig. 6. Survival rate of encapsulated and free L. acidophilus KBL409 after freeze-drying process with lyoprotectant.

Black bar indicates free cells, dotted bar indicates alginate-encapsulated cells, and gray bar indicates alginate/chitosan-encapsulated cells. (A-H) Different letters within same treatment (encapsulated and free cells) indicate statistical significance $(p<0.05)$. (a-c) Different letters with same lyoprotectant indicate statistical significance $(p<0.05)$. Con, control (no cryoprotectant); Lac, $10 \%$ lactose; Tre, $10 \%$ trehalose; Glu, $10 \%$ glucose; Suc, $10 \%$ sucrose; Fru, $10 \%$ fructose; Inu, 2\% inulin; Cor, $2 \%$ Corn; and Mal, $2 \%$ maltodextrin. 
extrusion method. The microspheres produced showed a narrow size distribution of less than $100 \mu \mathrm{m}$. Most cells $\mathbf{( 9 9 . 7 \% )}$ were entrapped in microspheres and the cell viability was high after encapsulation. To investigate the protective effect of microspheres in the gastrointestinal tract, free cells and encapsulated cells were exposed to SSF, SGF, and SIF with bile salts. Al/Chi-encapsulated cells showed the highest survival rate $(81.6 \%)$ after exposure to SGF for $2 \mathrm{~h}$, though alginate-encapsulated cells and free cells showed $63 \%$ and $46 \%$ viability, respectively $(p<0.05)$. After incubation with SGF and SIF for $4 \mathrm{~h}$, the survival rate of the encapsulated cells was higher than $40 \%$ versus free cells $(24.4 \%)$. Thus, the encapsulated cells were protected from gastrointestinal fluids. The mucoadhesive ability of microspheres was evaluated using HT29-MTX cells, which are similar to human intestinal epithelial cells. $\mathrm{Al}$ and $\mathrm{Al} /$ Chi-microspheres showed more than $94 \%$ adhesion rate, while the free cells showed an adhesion rate of $88 \%(p<$ 0.05). Experiments with FITC-labeled chitosan microspheres also confirmed the adhesion of the microspheres to intestinal epithelial cells. To evaluate the effect of lyoprotectants on the shelf-life of probiotics, all the cells and microspheres were freeze-dried with or without lyoprotectants. Free and encapsulated cells with $10 \%$ sucrose showed the highest survival rates after freeze-drying among all the treatments.

In conclusion, $\mathrm{Al} / \mathrm{Chi}$-microsphere encapsulation of $L$. acidophilus maintained the survival of cells and facilitated their delivery to the gastrointestinal tract. Microspheres showed improved mucoadhesion as compared to free L. acidophilus. Also, 10\% sucrose as a lyoprotectant showed high survival rate of free and encapsulated cells after freeze-drying.

\section{Acknowledgment}

This study was supported by the Industrial Strategic Technology Development Program (10076742, Development of probiotics for improvement of the chronic kidney disease from Korean gut microbes via correcting microbiota dysbiosis and decreasing uremic toxins) funded by the Ministry of Trade, Industry \& Energy (MOTIE, Korea). This study was also supported by the KU Research Professor Program of Konkuk University.

\section{Conflict of Interest}

The authors have no financial conflicts of interest to declare.

\section{References}

1. Shi LE, Li ZH, Li DT, Xu M, Chen HY, Zhang ZL, et al. 2013. Encapsulation of probiotic Lactobacillus bulgaricus in alginate-milk microspheres and evaluation of the survival in simulated gastrointestinal conditions. J. Food Eng. 117: 99-104.

2. Ooi LG, Liong MT. 2010. Cholesterol-lowering effects of probiotics and prebiotics: A Review of in vivo and in vitro findings. Int. J. Mol. Sci. 11: 2499-2522.

3. Knorr D. 1998. Technology aspects related to microorganisms in functional foods. Trends Food Sci. Technol. 9: 295-306.

4. Shahidi F, Han XQ. 1993. Encapsulation of food ingredients. Crit. Rev. Food Sci. Nutr. 33: 501-547.

5. Muthukumarasamy P, Allan-Wojtas P, Holley RA. 2006. Stability of Lactobacillus reuteri in different types of microcapsules. J. Food Sci. 71: 20-24.

6. Cook MT, Tzortzis G, Charalampopoulos D, Khutoryanskiy VV. 2011. Production and evaluation of dry alginate-chitosan microcapsules as an enteric delivery vehicle for probiotic bacteria. Biomacromolecules 12: 2834-2840.

7. Krasaekoopt W, Bhandari B, Deeth H. 2003. Evaluation of encapsulation techniques of probiotics for yoghurt. Int. Dairy J. 13: 3-13.

8. Martin MJ, Lara-Villoslada F, Ruiz MA, Morales ME. 2015. Microencapsulation of bacteria: a review of different technologies and their impact on the probiotic effects. Innov. Food Sci. Emerg. Technol. 27: 15-25.

9. Silva MP, Tulini FL, Martins E, Penning M, Favaro-Trindade CS, Poncelet D. 2018. Comparison of extrusion and coextrusion encapsulation techniques to protect Lactobacillus acidophilus LA3 in simulated gastrointestinal fluids. LWTFood Sci. Technol. 89: 392-399.

10. Rinaudo M. 2008. Main properties and current applications of some polysaccharides as biomaterials. Polym. Int. 57: 397430.

11. Gombotz WR, Wee S. 1998. Protein release from alginate matrices. Adv. Drug Deliv. Rev. 31: 267-285.

12. Chen S, Cao Y, Ferguson LR, Shu Q, Garg S. 2013. Evaluation of mucoadhesive coatings of chitosan and thiolated chitosan for the colonic delivery of microencapsulated probiotic bacteria. J. Microencapsul. 30: 103-115.

13. Khan NH, Korber DR, Low NH, Nickerson MT. 2013. Development of extrusion-based legume protein isolatealginate capsules for the protection and delivery of the acid sensitive probiotic, Bifidobacterium adolescentis. Food Res. Int. 54: 730-737.

14. Shori AB. 2017. Microencapsulation improved probiotics survival during gastric transit. HAYATI J. Biosci. 24: 1-5.

15. Bhumkar DR, Pokharkar VB. 2006. Studies on effect of $\mathrm{pH}$ on cross-linking of chitosan with sodium tripolyphosphate: a technical note. Pharm. Dev. Technol. 7: E138-E143.

16. Minekus $\mathrm{M}$, Alminger $\mathrm{M}$, Alvito $\mathrm{P}$, Balance $\mathrm{S}$, Bohn $\mathrm{T}$, Bourlieu C, et al. 2014. A standardized static in vitro 
digestion method suitable for food - an international consensus. Food Funct. 5: 1113-1124.

17. Oomen G, Rompelberg CJM, Bruil MA, Dobbe CJG, Pereboom DPKH, Sips AJAM. 2003. Development of an in vitro digestion model for estimating the bioaccessibility of soil contaminants. Arch. Environ. Contam. Toxicol. 44: 281-287.

18. Shinde T, Sun-Waterhouse D, Brooks J. 2014. Co-extrusion encapsulation of probiotic Lactobacillus acidophilus alone or together with apple skin polyphenols: an aqueous and value-added delivery system using alginate. Food Bioproc. Tech. 7: 1581-1596.

19. Lotfipour F, Mirzaeei S, Maghsoodi M. 2012. Preparation and characterization of alginate and payllium beads containing Lactobacillus acidophilus. Sci. World J. 2012: 680108.

20. Klemmer KJ, Korber DR, Low NH, Nickerson MT. 2011. Pea protein-based capsules for probiotic and prebiotic delivery. Int. J. Food Sci. Technol. 46: 2248-2256.

21. Heidebach T, Forst P, Kulozik U. 2009. Microencapsulation of probiotic cells by means of rennet-gelation of milk proteins. Food Hydrocoll. 23: 1670-1677.

22. Heidebach T, Forst P, Kulozik U. 2012. Microencapsulation of probiotic cells for food applications. CRC. Crit. Rev. Food Sci. Nutr. 52: 291-311.

23. Hansen LT, Allan-Wojtas PM, Jin YL, Paulson AT. 2002. Survival of Ca-alginate microencapsulated Bifidobacterium spp. in milk and simulated gastrointestinal conditions. Food Microbiol. 19: 35-45.

24. Kirby BJ, Hasselbrink JEF. 2004. Zeta potential of microfluidic substrates: 1 . Theory, experimental techniques, and effects on separations. Electrophoresis 25: 187-202.

25. Haidar ZS, Hamdy RC, Tabrizian M. 2008. Protein release kinetics for core-shell hybrid nanoparticles based on the layer-by-layer assembly of alginate and chitosan on liposomes. Biomaterials. 29: 1207-1215.

26. Chavarri M, Maranon I, Ares R, Ibanez FC, Marzo F, Villaran MC. 2010. Microencapsulation of a probiotic and prebiotic in alginate-chitosan capsules improves survival in simulated gastro-intestinal conditions. Int. J. Food Microbiol. 142: 185-189.

27. Ramos PE, Abrunhosa L, Pinheiro A, Cerqueira MA, Motta C, Castanheira I, et al. 2016. Probiotic-loaded microcapsule system for human in situ folate production: Encapsulation and system validation. Food Res. Int. 90: 25-32.

28. Sabikhi L, Babu R, Thompkinson DK, Kapila S. 2010. Resistance of microencapsulated Lactobacillus acidophilus LA1 to processing treatments and simulated gut conditions. Food Bioproc. Tech. 3: 586-593.

29. Zanjani MAK, Tarzi BG, Sharifan A, Mohammadi N. 2014. Microencapsulation of probiotics by calcium alginategelatinized starch with chitosan coating and evaluation of survival in simulated human gastro-intestinal condition. Iran. J. Pharm. Res. 13: 843-852.

30. Murata Y, Toniwa S, Miyamoto E, Kawahima S. 1999. Preparation alginate gel beads containing chitosan nicotinic acid salt and the functions. Eur. J. Pharm. Biopharm. 48: 49-52.

31. Koo S, Cho Y, Huh C, Baek Y, Park J. 2001. Improvement of the stability of Lactobacillus casei YIT 9018 by microencapsulation using alginate and chitosan. J. Microbiol. Biotechnol. 11: 376-383.

32. Gagnon M, Berner AZ, Chervet N, Chassard C, Lactoix C. 2013. Comparison of the Caco-2, HT-29 and the mucussecreting HT29-MTX intestinal cell models to investigate Salmonella adhesion and invasion. J. Microbiol. Methods 94: 274-279.

33. Anselmo AC, McHugh KJ, Webster J, Langer R, Jaklenec A. 2016. Layer-by-layer encapsulation of probiotics for delivery to the microbiome. Adv. Mater. 28: 9486-9490.

34. Rodklongtan A, La-ongkham O, Nitisinprasert S, Chitprasert P. 2014. Enhancement of Lactobacillus reuteri KUB-AC5 survival in broiler gastrointestinal tract by microencapsulation with alginate-chitosan semi-interpenetrating polymer networks. J. Appl. Microbiol. 117: 227-238.

35. He C, Shiwei C, Chuanna L, Guowei S. 2015. Response surface optimization of lyoprotectant for Lactobacillus bulgaricus during vacuum freeze-drying. Prep. Biochem. Biotech. 45: 463475.

36. Xiangchen M, Catherine SS, Gerald FF, Charles D, Ross P. 2008. Anhydrobiotics: The challenges of drying probiotic cultures. Food Chem. 106: 1406-1416.

37. Mimoza BS, Monika M, Sharareh S, Frank MU, Helmut V. 2014. Effect of lyoprotectants on $\beta$-glucosidase activity and viability of Bifidobacterium infantis after freeze-drying and storage in milk and low $\mathrm{pH}$ juices. LWT-Food Sci. Technol. 57: 276-282.

38. Maria S, Ilkka V, Liisa N, Anu V, Jaana M. 2006. Fibres as carries for Lactobacillus rhamnosus during freeze-drying and storage in apple juice and chocolate-coated breakfast cereals. Int. J. Food Microbiol. 112: 171-178.

39. Ananta E, Volkert M. Knorr D. 2005. Cellular injuries and storage stability of spray-dried Lactobacillus rhamnosus GG. Int. Dairy J. 15: 399-409.

40. Susanna R, Pirjo R. 2010. Protecting probiotic bacteria by microencapsulation: challenges for industrial applications. Eur. Food Res. Technol. 231: 1-12.

41. Heckly RJ. 1985. Principles of preserving bacteria by freezedrying. Dev. Ind. Microbiol. 26: 379-395.

42. Carpenter JF, Prestrelski SJ, Arakawa T. 1993. Separation of freezing- and drying-induced denaturation of lyophilized proteins using stress-specific stabilization: I. Enzyme activity and calorimetric studies. Arch. Biochem. Biophys. 303: 456-464. 